5. Сальнікова С. А. Багаторівневе моделювання як аналітична стратегія вимірювання релігійності / С. А. Сальнікова // Методологія, теорія і практика соціологічного аналізу сучасного суспільства : зб. наук. пр. Х. : ХНУ ім. В. Н. Каразіна, 2010. - Вип. 16. - С. 222-229.

\title{
References
}

1. "The Maidan and Church. Chronicle and expert assessment" (2014), Ed. by Fylypovych L. O. and Horkusha O. V., K. : Summit-book, 656 p.

2. Myronovych, D., Reshetniak, E., Salnikova, S. (2013), "Religious capital and religious participation in countries of new Eastern European”, Bulletin of Kyiv National Taras Shevchenko University. Sociology, Vol. 4, No. 1, Pp. 16-27.

3. Parashchevin, M. (2009), "Religion and religiosity in Ukraine”, K. : Institute of Politics, Institute of Sociology of NAS of Ukraine, $68 \mathrm{p}$

4. Salnikova, S. A. (2010), "Constructing the content, characteristics and levels of measuring the religiosity (according to empirical sociological research)", Ukrainian society, Vol. 35, No. 4, Pp. 108-119.

5. Salnikova, S. A. (2010), "Multidimensional modelling as analytical strategy of religiosity measurement", Methodology, theory and practice of sociological analysis of modern society, Issue 16, Pp. 222-229.

Билоус Людмила, Мартынюк Юлия. Уровень и характер религиозности лучан. В статье анализируется религиозность лучан согласно методике измерения религиозности путем многомерного моделирования (С. Сальникова) по данным социологического исследования (Луцк, 2015). Установлено, что религиозность жителей города является глубоко традиционной и сознательной и из-за событий на Майдане и Востоке Украины произошли изменения в ее структуре на уровне доверия к церкви и оттоку прихожан от Московского патриархата к Киевскому (от 3,8 до 4,4 \%).

Ключевые слова: религиозная вера, религиозные знания, религиозное поведение, религиозная мотивация, многоуровневое моделирование.

Bilous Liudmyla, Martynyuk Yulia. Level and Character of Religiosity of Lutsk Inhabitants. Analysis of Lutsk inhabitants' religiosity according to the data of social research (Lutsk, 2015) conducted by using methods of religiosity measuring by means of multilevel modelling (S. Salnikova) is provided in the article. It has been found that townsfolk' religiosity is strongly traditional (the townfolk believe in God, practice religious ritualism, and praying) and conscious (the responsibility for the human's suffering rest on themselves, but not in God). It was proved that events that took place on Maydan and East of Ukraine increased Lutsk inhabitants' trust to church without causing burst of church attendance and individual religiosity rise $(3,5)$. Changes happened in regard to the church that is trusted to: there are Lutsk parishioners' in the Ukrainian Orthodox Church of the Kyivan Patriarchate in three times more than in the UOC-MP, and Lutsk inhabitants' flow-out of Moscow Patriarchate to Kiev is from 3,8\% to 4,4\% during last year.

Key words: religious faith, religious knowledge, religious behaviour, religious motivation, multilevel modelling.

Статтю отримано 06.07.2015 p.

УДК 316.334.56.(477.82-25)

\section{Ольга Корецька}

\section{Стан районів міста Луцька очима його мешканців}

У роботі здійснено аналіз стану міста Луцька в цілому та його районів зокрема згідно 3 даними соціологічного опитування, проведеного в червні-липні 2015 p. (N=622, $\Delta \leq 0,05)$. Загалом лучани визначають «соціальний клімат» міста цілком прийнятним (3,5 бала 3 5-ти) й основні його проблеми такими: ремонт і встановлення нових дитячих/спортивних майданчиків (10,4\%); ремонт доріг (9,5\%); реорганізація сфери житлово-комунальних послуг $(7,9$ \%) тощо. Усталеність і типовість порядку нагальних проблем міста $\epsilon$ підставою для висновку про те, що лучани орієнтовані на розв'язання стандартних, або ж традиційних, проблем і майже не налаштовані на інноваційні, або ж перспективні, завдання.

Ключові слова: проблеми міста, стан районів міста, соціальний клімат міста, Луцьк.

(C) Кореиьька О., 2015 
Постановка наукової проблеми та їі значення. Місто - це не просто скупчення людей, промисловий чи культурний центр, це щось більше, ніж просто поселення. Саме в місті інтегрується все сучасне життя людей, це окремий світ зі своїми правилами, законами та проблемами. Неможливо знайти два однакові поселення з ідентичними атмосферою й устроєм.

Безперечно, кожне місто має свою структуру та планування. Вони вміщують кращі райони для життя й гірші, сповнені проблем та з мінімізованою їх кількістю. Відповідно до того, як різниться місто від міста, відрізняються й райони в середині цих міст. Кожен район - це сповнене самобутніх рис поселення, яке має свої характерні риси, водночас є невід’ємною частиною чогось цілого. Моніторинг проблем міста 3 його складовими частинами дає можливість виявляти сучасні тенденції соціально-економічного розвитку та стану міст.

Аналіз досліджень цісї проблеми. Міста з моменту свого виникнення зацікавили дослідників, котрі вивчали особливості міського стилю, недоліки й переваги такого життя тощо. Серед вітчизняних дослідників ці питання розробляли такі науковці, як Ю. Сорока, І. Прибиткова, О. Мусієздов, О. Лук'янченко, В. Сєвка та ін.

Звужуючи вивчення міської тематики до аналізу стану районів конкретного міста, ми акцентували увагу на емпіричному дослідженні міста Луцька; тут послуговувалися як результатами вже проведених досліджень іншими дослідниками (3. Герасимчук, О. Середа та ін.), так і емпіричними даними власного соціологічного проекту. Отож, стаття написана на основі емпіричних даних соціологічного дослідження «Соціальне самопочуття жителів міста Луцька», проведеного в межах виробничої практики (керівник - доц. С. А. Сальнікова) протягом червня-липня 2015 р. за участі автора (випадкова вибірка обсягом 622 особи сформована з урахуванням дизайн-ефекту $(1,56)$ і є репрезентативною за статтю та віком, похибка не перевищує $5 \%$, доступність респондентів становить 0,93 , польовий етап тривав із 29 червня по 5 липня).

Мета й завдання статті. Мета дослідження - виявлення та аналіз проблем міста Луцька загалом і його районів зокрема; задля цього буде здійснено (1) опис стану міста Луцька, (2) виявлення та деталізація проблем міста і його районів.

Виклад основного матеріалу та обгрунтування отриманих результатів дослідження. Як стверджують О. Лук'янченко та В. Сєвка, спосіб життя городян і стан міста загалом безпосередньо пов'язані з оцінкою рівня зайнятості населення, забезпечення громадського порядку й особистої безпеки за підтримки сприятливого соціально-психологічного клімату в суспільстві. Усі ці показники фіксують ситуацію, наявну в місті на певний час [3]. Так, наприклад, проаналізувавши думки респондентів щодо ситуації в Луцьку станом на червень 2015 р., можна зробити висновок, що «соціальний клімат» міста є цілком прийнятним, адже ситуацію як задовільну визначають 44,9\% лучан, тоді як 37,7 \% - називають іï спокійною й 17,4 \% - тривожною. Щодо вікового розрізу, то задовільною вважають ситуацію в місті, зазвичай, особи віком $18-29$ (12,1\%) та 54-65 (13,1\%). Така позитивна оцінка стану міста, безперечно, не може не тішити, ураховуючи складну ситуацію в Україні, зокрема в багатьох іï східних містах.

Таблиия 1

Залежність сприйняття ситуації в місті від віку респондентів, \%

\begin{tabular}{|l|c|c|c|c|c|}
\hline \multirow{2}{*}{$\begin{array}{c}\text { Ситуація } \\
\text { в місті }\end{array}$} & \multicolumn{4}{|c|}{ Вікові проміжки } & \multirow{2}{*}{ Усього } \\
\cline { 2 - 5 } & $\mathbf{1 8 - 2 9}$ & $\mathbf{3 0 - 4 1}$ & $\mathbf{4 2 - 5 3}$ & $\mathbf{5 4 - 6 5}$ & 12,6 \\
\hline Спокійна & 8,5 & 8,3 & 8,1 & 13,1 & 47,5 \\
\hline Задовільна & 12,1 & 11,2 & 8,5 & 8,3 & 17,5 \\
\hline Тривожна & 1,6 & 4,2 & 3,5 & 34,1 & 100,0 \\
\hline Усього & 22,1 & 23,7 & 20,1 & \\
\hline
\end{tabular}

Якщо говорити про стан міста загалом, то за п'ятибальною шкалою іiї оцінюють непогано - у 3,48 бала, при цьому найбільше лучани обирали оцінки 4 (43\%) і 3 (37\%) (найнижчу оцінку в 1 бал зазначило 1,9 \% опитаних, 2 бали $-10,6 \%, 3$ бали - 36,8 \%, $4-42,7 \%, 5-8 \%)$. Отож, лучани у своїй більшості задоволені станом міста, у якому вони проживають.

Можливість мешканців оцінити стан свого району за 3-бальною шкалою, де 1 - найнижча оцінка, 3 - найвища, виявила певний порядок престижності районів міста, при цьому найбільшу кількість позитивних оцінок отримали Центр-2 (проспект Волі та прилеглі вулиці) - 75,8 \%, Старе 
місто і Центр-1 - 75,0 \% та райони Варшавського ринку й 40-А - 59,8 \%. Окрім Дубнівського, 40-Б та Львівського районів, усі решта оцінюються вищим за середній балом, значення якого для міста загалом становить 2,26.

Таблиия 2

Оцінка стану району, \%, сер. бал

\begin{tabular}{|l|c|c|c|c|}
\hline \multirow{2}{*}{ Район міста } & \multicolumn{3}{|c|}{ Оцінка } & \multirow{2}{*}{ Сер. бал } \\
\cline { 1 - 4 } & $\mathbf{1}$ & $\mathbf{2}$ & $\mathbf{3}$ & 2,72 \\
\hline Центр-2 & 6,1 & 18,2 & 75,8 & 2,66 \\
\hline Старе місто і Центр-1 & 6,3 & 18,8 & 75,0 & 2,52 \\
\hline Варшавський - 40-А & 7,3 & 32,9 & 59,8 & 2,33 \\
\hline Балка & 16,7 & 33,3 & 50,0 & 2,32 \\
\hline 33-й - 55-й & 18,0 & 31,1 & 50,8 & 2,31 \\
\hline Вокзал & 14,9 & 38,3 & 46,8 & 2,20 \\
\hline Перемоги & 8,3 & 62,5 & 29,2 & 2,19 \\
\hline ДПЗ & 19,4 & 41,8 & 38,8 & 2,12 \\
\hline Відродження & 13,3 & 60,0 & 26,7 & 2,07 \\
\hline Вишків & 23,5 & 47,1 & 29,4 & 2,00 \\
\hline Львівська & 31,1 & 37,8 & 31,1 & 1,90 \\
\hline 40-й Б & 37,5 & 33,3 & 29,2 & 1,85 \\
\hline Дубнівська & 40,9 & 31,8 & 27,3 & \\
\hline
\end{tabular}

Отже, ми можемо спостерігати той факт, що більшість лучан задоволені своїм районом проживання або традиційно вважають, що більш престижні райони мають кращу інфраструктуру та більше зручностей, порівняно $з$ іншими. Респондентам запропоновано також назвати особливу ознаку (позитивну й негативну), характерну для району міста, де вони проживають. Результати відображено в табл. 3. Вони можуть слугувати орієнтиром для тих, хто займається благоустроєм міста.

Таблиия 3

Ознаки районів міста

\begin{tabular}{|c|c|c|}
\hline Район міста & Позитивна ознака & Негативна ознака \\
\hline 1 & 2 & 3 \\
\hline ДПЗ & Наявність місць для відпочинку & Наявність безпритульних \\
\hline Львівська & Тихий; озеленений; затишний & $\begin{array}{l}\text { Неконтрольований рух автомобілів; } \\
\text { неналежний стан виробничої } \\
\text { інфраструктури (дороги, міська } \\
\text { каналізаційна система) }\end{array}$ \\
\hline Старе місто і Центр-1 & Розміщення; чисто; озеленений & $\begin{array}{l}\text { Недостатня кількість урн для сміття; } \\
\text { немає місця для паркування; занедбаний } \\
\text { зовнішній вигляд будинків }\end{array}$ \\
\hline Центр-2 & Тихий; озеленений & $\begin{array}{l}\text { Наявність стихійної торгівлі на вулицях; } \\
\text { порушення громадського спокою }\end{array}$ \\
\hline Вокзал & Наявність місць для відпочинку & $\begin{array}{l}\text { Наявність наркоманів; неналежний стан } \\
\text { під'їздів }\end{array}$ \\
\hline Перемоги & $\begin{array}{l}\text { Близьке розміщення залізничного } \\
\text { вокзалу }\end{array}$ & Шумно \\
\hline Варшавський - 40-А & $\begin{array}{l}\text { Зручне розміщення; почали } \\
\text { ремонтувати дороги }\end{array}$ & $\begin{array}{l}\text { Шумно; велика кількість розважальних } \\
\text { закладів }\end{array}$ \\
\hline 33-й і 55-й & Тихо; чисто; ремонт доріг & $\begin{array}{l}\text { Завантаженість дитсадків; погане } \\
\text { освітлення вулиць; алкоголізм }\end{array}$ \\
\hline
\end{tabular}


Закінчення таблииі 3

\begin{tabular}{|l|l|l|}
\hline \multicolumn{1}{|c|}{1} & \multicolumn{1}{|c|}{2} & \multicolumn{1}{|c|}{3} \\
\hline Варшавський - 40-Б & $\begin{array}{l}\text { Хороша інфраструктура; наявність } \\
\text { дитячих майданчиків, озеленена } \\
\text { територія, парк поблизу }\end{array}$ & $\begin{array}{l}\text { Неналежний стан доріг; відсутність } \\
\text { освітлення, гарячої води; недостатня } \\
\text { кількість дитячих садочків }\end{array}$ \\
\hline Вишків & Спокійний; чисте повітря & $\begin{array}{l}\text { 3никає часто світло; неналежна } \\
\text { iнфраструктура }\end{array}$ \\
\hline Дубнівська & Чистий; озеленений & $\begin{array}{l}\text { Відсутність необхідної кількості аптек; } \\
\text { загромадження вулиць автомобілями }\end{array}$ \\
\hline Балка & Тихий & $\begin{array}{l}\text { Стан дорожнього покриття у дворах; } \\
\text { алкоголізм }\end{array}$ \\
\hline Відродження & $\begin{array}{l}\text { Близьке розміщення лікарні, } \\
\text { магазинів }\end{array}$ & $\begin{array}{l}\text { Ненатність місць для паркування; } \\
\text { водостоків; наявність бродячих собак }\end{array}$ \\
\hline
\end{tabular}

Загалом порядок значимих проблем міста Луцька виявився таким (див. табл. 4).

Таблиия 4

\begin{tabular}{|c|c|}
\hline Проблема & $\%$ \\
\hline Ремонт та встановлення нових дитячих/спортивних майданчиків & 10,4 \\
\hline Ремонт доріг & 9,5 \\
\hline Реорганізація сфери житлово-комунальних послуг & 7,9 \\
\hline Запланована реконструкція Театрального майдану & 6,9 \\
\hline Сприяння розвитку малого й середнього бізнесу & 5,7 \\
\hline Підтримка заходів науково-технічного розвитку школярів і студентів & 5,8 \\
\hline Забезпечення місць для відпочинку (парки, сквери) & 5,4 \\
\hline Екологічна ситуація міста & 4,9 \\
\hline Якість медичних послуг, вартість медичного обстеження & 4,7 \\
\hline Стихійна забудова & 4,6 \\
\hline Урегулювання стихійної торгівлі на вулицях міст & 4,4 \\
\hline Збереження історичних пам’яток & 4,1 \\
\hline Відсутність велосипедних доріжок, пандусів, тротуарів тощо & 4,1 \\
\hline Збільшення кількості розважальних закладів & 3,9 \\
\hline Якість роботи громадського транспорту & 3,8 \\
\hline Сприяння й розширення соціальних заходів для людей літнього віку & 3,8 \\
\hline Добудова фонтану в центрі міста & 3,7 \\
\hline Будівництво соціального житла & 2,9 \\
\hline Обов’язковість благодійних внесків (медицина, правоохоронна система, освіта) & 2,6 \\
\hline Усього & 100,0 \\
\hline
\end{tabular}

Згідно з даними табл. 4, однією з найбільш поширених і нагальних проблем для Луцька є ремонт та встановлення нових дитячих/спортивних майданчиків. Це й не дивно, адже в місті спостерігаються стабільно високі показники народжуваності та природного приросту населення ${ }^{2}$. Зрозуміло, що ця проблема більш актуальна для сімей, які мають малолітніх дітей. Крім того, проблема щодо ремонту та встановлення таких майданчиків $є$ дійсно значимою й не лише для м. Луцька, про що свідчить низка публікацій ${ }^{3}$.

\footnotetext{
${ }^{1}$ У цій таблиці зазначено перший із трьох можливих виборів респондента як найголовніший.

2 У Луцьку за 2013 рік народилося 2650 немовлят, тоді як природний приріст становить 692 особи. А у $2014-20705$ та 592 особи відповідно. Також у 2013 р. в Луцьку нараховувалося 211,6 тис. осіб у віці від 0-15 років, а у 2014 - 213,8 тис. [5].

3 Її вивчали Ю. Рубець у своїй публікації «Проблеми образотворення дитячих майданчиків м. Луцька», К. Глаголєва та В. Чернявський у статті «Особливості створення дитячих майданчиків в структурі сучасного міста».
} 
Якщо враховувати виробничу та соціальну інфраструктури міста, то можна стверджувати, що відповідні питання (ремонт доріг, реорганізація сфери житлово-комунальних послуг тощо) $є$ доволі болючими для жителів міста, адже проблеми благоустрою й стану інфраструктури завжди «очолюють» списки проблем міста [4].

Цікавим також видається те, що проблема відсутності велосипедних доріжок, пандусів, тротуарів тощо цікавить лучан менше, ніж, наприклад, сприяння розвитку малого та середнього бізнесу. Така ситуація може бути спричинена тим, що сучасна молодь $є$ доволі активною й потребує нових зручностей; або тим, що Луцьк є європейсько орієнтованим містом і прагне запроваджувати європейські стандарти; або ж тим, що питання відсутності велосипедних доріжок, пандусів, тротуарів часто піднімають засоби масової інформації, тоді як про проблему, наприклад, сприяння й розширення соціальних заходів для людей літнього віку «знають» лише певні зацікавлені категорії населення чи деякі громадські об'єднання.

Усе ж таки відповідно до результатів нашого й попередніх досліджень можемо стверджувати, що проблема мобільності, благоустрою вулиць та власної домівки стоїть досить гостро, $є$ основною не тільки на сьогодні [2].

Щодо проблем, які є домінуючими для мешканців певного району за останній рік, лучани виокремили такі:

- ДПЗ - відсутність місць для відпочинку або їх неналежний стан, стан доріг району, якість надання ЖКП.

- Львівська - освітлення вулиць, стан доріг району, якість надання ЖКП.

- Вокзал - відсутність місць для відпочинку або їх неналежний стан, стан доріг району, якість надання ЖКП.

- Старе місто й Центр-1 - відсутність місць для відпочинку або їх неналежний стан, якість надання ЖКП.

- Перемоги - стан дорожного покриття у дворах.

- Варшавський - 40-А - відсутність місць для відпочинку або їх неналежний стан, завантаженість дитсадків та шкіл, стан доріг району.

- 33-55-й райони - відсутність місць для відпочинку або їх неналежний стан, завантаженість дитсадків та шкіл, стан доріг району.

- Район 40-й-Б - стан доріг району, якість надання ЖКП.

- Дубнівська - відсутність місць для відпочинку або їх неналежний стан, стан доріг району.

- Балка - відсутність місць для відпочинку або їх неналежний стан, якість надання житловокомунальних послуг.

- Відродження - якість надання ЖКП.

Аналізуючи проблеми кожного окремого району, можна помітити певну схожість: жителі більшості районів у тій чи іншій мірі стикаються з неналежним станом інфраструктури. Результати нашого дослідження не $є$ унікальними, а лише підтверджують сумну статистику як нашого, так i інших міст України. Про нагальність вирішення цих питань, зокрема, ідеться в роботі 3. Герасимчук та О. Середи «Стратегічне управління сталим розвитком м. Луцька: проблеми та перспективи». Науковці визначають актуальність проблеми щодо стану соціальної інфраструктури міста, особливо житлово-комунального господарства та сфери охорони здоров'я. Актуальними, на їхню думку, для Луцька є й проблеми екологічного характеру, як і для інших міст - обласних центрів, а саме: ті, що пов'язані з використанням свіжої води та фінансуванням природоохоронної діяльності, низького рівня озеленення й забруднення атмосферного повітря, утилізації та переробки відходів, що в підсумку зумовлює несприятливу екологічну ситуацію міста [1]. Дані нашого дослідження підтверджують важливість екологічних проблем для багатьох лучан. Жителі переймаються наявністю сміття на вулицях, вони хочуть бачити своє місто більш зеленим та охайним. Але, на жаль, на сьогодні важко помітити хоч якісь значимі позитивні зрушення в розв'язанні екологічних проблем. Безперечно, самі жителі й влада міста роблять певні спроби в розв'язанні цих питань: суботники, акції з озеленення та благоустрою міста, просвітницька діяльність у школах і вищих навчальних закладах тощо. Усі ці акції можна класифікувати як такі, що спрямовані на «підтримання порядку», а не як рішучі та/або інноваційні кроки щодо підтримання екології (використання 
виключно електротранспорту в межах міста, утилізація сміття, створення інфраструктури для переміщення велотранспортом тощо).

Висновки. Послуговуючись даними соціологічного опитування, ми виявили та проаналізували найбільш поширені проблем міста Луцька та його районів. Результати дослідження свідчать, що для всіх районів Луцька актуальним є виконання таких завдань, як ремонт доріг, ремонт та встановлення нових дитячих/спортивних майданчиків, якість надання житлово-комунальних послуг. Можемо стверджувати про неякісне усунення цих недоліків по всьому Луцьку й про їх надто уповільнене вирішення. Але варто також зазначити, що проблеми, які лучани називають частіше за інші, є доволі усталеними та стандартними. Про їх наявність часто повідомляють засоби масової інформації й на них, передусім, звертають увагу чиновники; інші ж - лишаються поза публічною дискусією. Отож жителі міста орієнтовані на розв'язання стандартних, або ж традиційних, проблем і майже не налаштовані на інноваційні, або ж перспективні, завдання. Отже, можемо констатувати, що жителі міста $з$ певних причин не виходять за певні усталені рамки, вони орієнтовані на порядок та стандарти й не бажають поступатися звичками заради змін, нехай і на краще.

Незважаючи на всі ці суперечності й проблеми, лучани в цілому задоволені тими районами міста, у яких проживають; вони їх люблять і намагаються піклуватися про них (прибирають, ремонтують, озеленюють). Також лучани задоволені й самим містом, вони відчувають себе захищеними та певною мірою впевненими в майбутньому, відповідно зростає й загальна їх задоволеність життям.

\section{Досерела та література}

1. Герасимчук 3. В. Стратегічне управління сталим розвитком м. Луцька: проблеми та перспективи / 3. В. Герасимчук, О. В. Середа // Економічні науки. - Серія : «Регіональна економіка» : зб. наук. пр. - Луцьк : ЛНТУ, 2014. - № 11 (43). - С. 60-74.

2. Демчук С. Молоді лучани за ремонт доріг, підземний перехід і довіряють громадським організаціям [Електронний ресурс] / С. Демчук // Асоціація молодих політиків і політологів. - 2008. - Режим доступу : http://politolog-volyn.org/discovery/statti/92-infrastruktura-lutsk

3. Лук'янченко О. О. Формування системи моніторингу якості життя населення міст / О. О. Лук’янченко, В. Г. Сєвка // Економіка будівництва і міського господарства. - 2012. - Т. 8, № 3. - С. 219-226.

4. Сальнікова С. А. Місто крізь призму соціального самопочуття [Електронний ресурс] / С. А. Сальнікова. - 2009. - Режим доступу : http://esnuir.eenu.edu.ua/bitstream/123456789/1253/1/Article..pdf

5. Державна служба статистики України. Головне управління статистики у Волинській області [Електронний ресурс]. - Режим доступу : http://www.lutsk.ukrstat.gov.ua/

\section{References}

1. Herasymchuk, Z. V., Sereda, O. V. (2014), "Strategic sustainability management in Lutsk: problems and prospects”, Economics. A series of «Regional Economy», Vol. 43, No. 11, Pp. 60-74.

2. Demchyk, S. (2008), "Young people of Lutsk for the repair of roads, underpass and public organizations trust", http://politolog-volyn.org/discovery/statti/92-infrastruktura-lutsk

3. Lukyanchenko, O. O., Syevka, V. H. (2012), "The formation of monitoring of quality of life in cities", Ekonomika budivnytstva i miskoho hospodarstva, Vol. 8, No. 3, Pp. 219-226.

4. Salnikova, S. A. (2009), "City through the lens of social well-being", http://esnuir.eenu.edu.ua/ bitstream/123456789/1253/1/Article..pdf

5. "State Statistics Service of Ukraine. Department of Statistics in Volyn region", http://www.lutsk.ukrstat.gov.ua/

Корецкая Ольга. Состояние районов города Луцка глазами его жителей. В статье произведен анализ состояния города Луцка в целом (3,5 балла из 5-ти) и его районов согласно данным социологического опроса $(\mathrm{N}=622, \Delta \leq 0,05,2015$ г.). Учитывая постоянство и типичность насущных проблем города (ремонт и установка новых детских / спортивных площадок - 10,4 \%; ремонт дорог - 9,5 \%; реорганизация сферы жилищно-коммунальных услуг - 7,9 \%), делаем вывод, что жители города более ориентированы на решение традиционных, а не перспективных задач.

Ключевые слова: проблемы города, состояние районов города, социальный климат города, Луцк.

Koretskaya Olga. Condition of Lutsk's Districts in Terms of its Residents. The analysis dealing with the condition of the city of Lutsk as a whole and its districts in particular has been made herein according to the data of the 
opinion poll held in June-July $2015(\mathrm{~N}=622, \mathrm{~A}<$ _0,05). In general, the citizens residing in Lutsk are estimated its «social climate» as quite acceptable (rating 3,5 from 5,0 points) and its fundamental problems are determined as follows: the maintenance of existing and construction of new children's playgrounds and athletic fields (10,4 \%); reconditioning of roads $(9,5 \%)$; reorganization of housing and utilities sector $(7,9 \%)$, etc. A sequence of urban pressing challenges is firmly established and typical giving grounds to the author's conclusion that the urban citizens are much more concentrated on the solutions of standard or traditional problems than to be focused on innovational or perspective issues such as the exploitation of exclusively e-Mobility within the city, recycling of waste, infrastructure development for getting around by any bike transport, organization of leisure time for people of old age, etc.).

As can be seen from the above, Lutsk is characterized as rather traditional city whose inhabitants are focused on the order and following standards.

Key words: problems of the city, condition of urban districts, social climate of the city, Lutsk.

Статтю отримано 08.07.2015 p.

УДК $316.77(075.8)$

\section{Оксана Нехаенко}

\section{Влияние социальных сетей на формирование массового политического сознания}

Обосновывается необходимость изучения политического сознания через средства массовой коммуникации как главного транслятора государственных идеологий, оказывающего значительное воздействие на политическое сознание, в первую очередь посредством знаков и символов. С целью определения факторов такого влияния проводится дискурс-анализ двух социальных сетей. Установлено, что используемые механизмы влияния и технические приёмы противоборствующих политических сил и направлений зачастую практически тождественны.

Ключевые слова: политическое сознание, социальные сети, идеология, социальный контроль, символическое измерение реальности.

Постановка научной проблемы и ее значение. Одной из главных характеристик современности является растущее влияние политического сознания (как особой формы общественного) на социальные явления и процессы. Как отмечает российский политолог Н. А. Баранов, такая тенденция обусловлена либерализацией политических систем [1]. Во-первых, подобный рост можно объяснить тем, что в конце XX в. происходили значительные изменения в мировой политической системе. Главным образом здесь подразумеваются трансформационные процессы в Восточной и Центральной Европе конца 1980 - начала 1990-х годов. Любые изменения социальной структуры актуализируют исследование природы и сущности характеристик политического сознания, его фундаментальных ценностей, поскольку переход от одной модели политического и социально-экономического устройства к другой обусловливает сдвиги в массовом политическом сознании. Во-вторых, значительное влияние на изменения сознания людей оказывает разветвлённая сеть средств массовой коммуникации. СМИ превратились в силу, способную формировать мышление и сознание масс: они выступают в качестве катализаторов и проводников идеологических мифов и паттернов. Проблема заключается в том, что при всей очевидности усиления влияния социально-психологических аспектов на общественную жизнь в целом и политические процессы в частности открытыми остаются следующие вопросы: 1) каковы предпосылки возникновения этой тенденции; 2) какова степень её влияния на формирование массового сознания; 3) какие инструменты воздействия наибольше востребованы сегодня в информационном пространстве; 4) какое место отводится политическим мифам в системе массового сознания.

Собственно, в этом заключается актуальность данной статьи: важно выявить инструменты, о которых говорилось выше, и осуществить попытку осмысления механизмов их функционирования. Кроме того, стоит отметить особую актуальность социологического подхода к изучению социальнополитического сознания (в частности, факторов формирования идеологических образцов и шаблонов). Сегодня, в условиях активного развития политических, рекламных и пропагандистских технологий, изучение особенностей функционирования СМК (в том числе и социальных сетей)

(C) Нехаенко О., 2015 